\title{
SERUM LEVELS OF ALPHA-MELANOCYTE STIMULATING HORMONE, VITAMIN D, CALCIUM, PHOSPHORUS AND MAGNESIUM IN COVID-19 PATIENTS
}

\author{
S. Z. HUSSEIN ${ }^{1}$, M. A. ABDALLA ${ }^{2 \bowtie}$ \\ ${ }^{1}$ Clinical Biochemistry Unit, Salah Aldeen Health Directorate, Tikrit, Iraq; \\ ${ }^{2}$ Department of Human Anatomy, Tikrit University College of Medicine, Tikrit, Iraq; \\ ®e-mail:dr.mohammad68@tu.edu.iq
}

Received: 04 April 2021; Accepted: 12 November 2021

The COVID-19 pandemic occurred and quickly spread throughout the world. To improve the state of COVID-19 patients, it is important to identify the possible clinical differential diagnostic markers and their correlation with the severity of SARS-CoV-2 infection. In this study, the serum level of alpha-melanocyte stimulating hormone (alpha-MSH), vitamin D, calcium, phosphorus and magnesium in the serum of COVID-19 patients were analyzed. Blood samples were collected from 60 patients who attended Isolated Hospital in Tikrit City/Iraq from September to December 2020 and diagnosed by RT-PCR as COVID-19 positive and from 30 healthy individuals. It was shown that COVID-19 patients revealed high serum levels of $\alpha$-MSH as compared with healthy individuals but low serum levels of vitamin D, calcium, and magnesium which may be recommended as supplements for those patients to increase the innate immune response.

Ke y w ord s: COVID-19, alpha-MSH, calcium, magnesium, vitamin D.

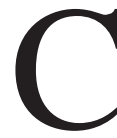

OVID-19 virus (SARS-CoV-2) is a member of the Coronaviridae family. The first infections were discovered in November 2019 in Wuhan, Hubei city in the center of China. Then this pandemic was pervasion to other many countries around the world [1].

Melanocortins are considered immunomodulatory and anti-inflammatory markers. Their physiological role and effectiveness in the treatment of chronic, acute, and systemic inflammatory disorders were well-documented. Melanocortin pathways could form a real basis against the negative consequences of respiratory viruses not only for now but also for feasible future pandemics [2, 3].

Melanocortins are a group of endogenous peptides released by cells of the central and peripheral nervous systems. Proopiomelanocortin (POMC) was the precursor of these peptides, which also include the melanotropins ( $\alpha, \beta$, and $\gamma$ - MSH) and adrenocorticotropic hormone (ACTH). Even though, MSH has been identified as a melanogenic hormone and the action of ACTH is confined to its steroidal effect, the melanocortins have multiple physiological actions on the host [4-6].

Melanocortin pathway activates with synthetic or natural ligands and has beneficial effects in acute or chronic and systemic inflammatory disorders $[5,6]$. Clinical articles have shown the efficacy of [Nle4, D-Phe7]-alpha-MSH (NDP- $\alpha-\mathrm{MSH})$ and $\mathrm{ACTH}$ therapies in systemic inflammatory disorders like kidney diseases, acute respiratory distress syndrome (ARDS), rheumatoid arthritis (RA), multiple sclerosis (MS), systemic lupus erythematosus (SLE), and nephrotic syndrome (NS) [7-11].

The high evidence of the different immunomodulating effects of melanocortins is conducted among special melanocortin receptor (MCR) targeting by activation of the MC1R and MC3R, immunological regulation occurs by MC5R. For example, inflammatory response inhibited by macrophages, MC1R and MC3R, while MC5R associated with differentiation of monocyte toward

(C) 2021 Hussein S.Z., Abdalla M.A. This is an open-access article distributed under the terms of the Creative Commons Attribution License, which permits unrestricted use, distribution, and reproduction in any medium, provided the original author and source are credited. 
the tolerogenic antigen-presenting cells (APCs) or myeloid suppressor cells with subsequent decreased the activation effects of T cells [12-14].

In COVID-19, most studies used corticosteroidbased therapy in critical and severe patients whose state could be improved from the action of glucocorticoids. ACTH therapy needs a preventative evaluation to identify the balance between harms and improvements of enhancing corticosteroids [15].

The $1,25(\mathrm{OH})_{2} \mathrm{D}_{3}$, which is the active form of vitamin $\mathrm{D}$, is produced in the immune cells and stimulated numerous gene expression referred to as healthy immune responses. The $1,25(\mathrm{OH})_{2} \mathrm{D}_{3}$ also acts on different kinds of epithelial cells and affects their immune defense mechanisms. In addition, the important advantage of vitamin D sufficiency may be its inhibitory effect on increased cytokine production that can be a deadly consequence of acute infections of many respiratory viruses [16-18].

Most calcium of the human body presents in the bones, while the rest circulates in the blood. About one-half of the calcium is referred to as "ionized"or "free" and it is the active form. The other half is "bound" calcium which is attached to albumin and other compounds and is the metabolically inactive form [19]. The total calcium is the calculation of both previous types. Changes in albumin concentration cause a change in total calcium without affecting the physiological and clinical importance of ionized calcium fraction. Therefore, the corrected calcium was calculated by using different formulas when albumin was below the reference range. The consumption of circulating calcium that helps the virus to enter into host cells may be one of the causes of hypocalcemia; therefore, this hypocalcemia in COVID-19 hospitalized patients may be a marker of severe illness and was common in critical patients admitted to the intensive care unit (ICU). Viruses are also can used the calcium ion signal to create a suitable cellular environment that associated with their demands [20].

Hypophosphatemia in acute respiratory failure or chronic obstructive pulmonary patients had been reported in previous studies [21]. Therefore, it is an important issue to understand the clinical correlation of calcium and phosphorus levels with the severity of SARS-CoV-2 infection and to investigate the use of COVID-19 clinical differential diagnostic markers [22].

The functions of magnesium $\left(\mathrm{Mg}^{+2}\right)$ include playing a role in the bronchodilatation and relaxation of bronchial smooth muscle, antihistaminic, anticholinergic, and anti-inflammatory effects. There- fore, the harmful effect of prolonged magnesium deficiency on lung function of COVID- 19 patients can be assumed [23]. To our best knowledge, at the moment there are no data about magnesium homeostasis in COVID-19 patients, which is not surprising because magnesemia is not routinely evaluated in clinical practice [24].

Therefore, the present study aims to evaluate the alpha-MSH, $1,25(\mathrm{OH})_{2} \mathrm{D}_{3}$, calcium, phosphorus, magnesium, and albumin serum levels in positively infected COVID-19 patients.

\section{Material and Methods}

The Medical Ethics Committee of Tikrit University College of Medicine had approved this study with the code number (IQ.TUCOM.REC.2020.C86). Ethical agreement statement was acquired from all individuals in this study, according to the World Medical Association Declaration of Helsinki, revised in 2000, Edinburgh.

A case-control study includes 60 patients who developed signs and symptoms that appeared like fever, cough, fatigue, and headache for at least (5-7) days after the appearance of these clinical features. All patients were diagnosed as positive COVID-19 infection with a pharyngeal swab that was positive by RT-PCR. Blood samples were collected from all those 60 patients who attended to Isolated Hospital in Tikrit City/Iraq in the period from September to December 2020 and another 30 samples from healthy individuals.

Alpha-MSH and $1,25(\mathrm{OH})_{2} \mathrm{D}_{3}$ levels were estimated by ELISA kits (Sunlong Company) [25] and calcium (total, ionized, and corrected), phosphorus, and magnesium content were measured by BioLabo kits. All individuals were ranged (20-70) years, and they were non-diabetics and non-smokers with no personal and familial history of diabetes, hypertensive, thyroid, and renal diseases.

Statistical analysis was done by using the SPSS version 25 statistical program, and a comparison was made between various groups, which were evaluated by two independent sample $t$-test. The level of statistical significance was calculated at $(P<0.05)$.

\section{Results}

In the present study, the mean \pm SD of $\alpha$-MSH level in COVID-19 patients was increased $(386.57 \pm 132.86 \mathrm{pg} / \mathrm{ml})$ with a significant difference $(P=0.029)$ when compared with healthy individuals $(330.27 \pm 56.4 \mathrm{pg} / \mathrm{ml})$. 
On the other hand, the mean \pm SD of $1,25(\mathrm{OH})_{2} \mathrm{D}_{3}$ level in COVID-19 patients was lower $(14.73 \pm 4.16 \mathrm{ng} / \mathrm{ml})$ compared with healthy individuals $(22.8 \pm 4.6 \mathrm{ng} / \mathrm{ml})$ with a highly significant difference $(P<0.0001)$, as shown in Table $(1)$.

In this study, the findings showed that there was a highly significant difference $(P<0.0001)$ in the levels of calcium (total, ionized, and corrected) $(8.28 \pm 0.60,4.24 \pm 0.45$, and $8.44 \pm 0.80 \mathrm{mg} / \mathrm{dl})$ respectively in COVID-19 patients when compared with healthy individuals $(9.40 \pm 0.65,4.55 \pm 0.43$, and $9.02 \pm 0.88 \mathrm{mg} / \mathrm{dl}$ ) respectively, as seen in Table.

In the current study, the mean $\pm S D$ of phosphorus and magnesium in COVID-19 patients were (3.94 \pm 0.40 and $1.78 \pm 0.11 \mathrm{mg} / \mathrm{dl})$ respectively, while in healthy individuals were (4.02 \pm 0.46 and $1.92 \pm 0.20 \mathrm{mg} / \mathrm{dl})$ respectively. The mean $\pm \mathrm{SD}$ of albumin in COVID-19 patients was (3.78 $\pm 0.74 \mathrm{~g} /$ dl) but in healthy individuals was $(4.20 \pm 0.54 \mathrm{~g} / \mathrm{dl})$. These results showed that there was no significant difference $(P=0.397)$ of phosphorus in COVID-19 patients but in magnesium and albumin levels there was a highly significant difference $(P<0.0001$ and $P=0.007$ ) respectively in COVID-19 patients when compared with healthy individuals, as revealed in Table.

\section{Discussion}

In this study, $\alpha$-MSH was increased in COVID-19 patients but vitamin D was decreased when compared with healthy individuals. Like $\mathrm{ACTH}$, it is expected that the anti-inflammatory effect of $\alpha$-MSH may be stimulated by particular MCRs expressed in hypothalamic neurons and peripheral immune cells. The inflammation modula- tory signaling pathways were stimulated by $\alpha-\mathrm{MSH}$ in the central nervous system which is expected to act through neural MC4R [26,27]. MC1R and MC5R can play an important role in the modulation of proinflammatory cytokines and collagens by $\alpha-\mathrm{MSH}$ in human articular chondrocytes. Moreover, beneficial effects influence $\alpha$-MSH is an autoimmune uveoretinitis needed a functional MC5R [28].

In COVID-19 patients, the innate immune system develops both the pro-inflammatory and the anti-inflammatory specific cytokines. Vitamin D has been revealed to decrease the formation of $\mathrm{T}$ helper cell type 1 (Th1) to cytokines like interferon and tumor necrosis factor-alpha (TNF- $\alpha$ ). Furthermore, vitamin $\mathrm{D}$ administration reduces the production of pro-inflammatory cytokines in macrophage cells while increasing the expression of anti-inflammatory cytokines $[29,30]$. Therefore, the low level of $1,25(\mathrm{OH})_{2} \mathrm{D}_{3}$ in the current study may be due to the inflammatory process that needs a great amount of active form of vitamin $\mathrm{D}$ because of its anti-inflammatory role. Ultimately, the consumption of vitamin D in the cells implicated in immunomodulation is increased, resulting in reduction of its inactive form level in serum. From this perspective, the low level of $1,25(\mathrm{OH})_{2} \mathrm{D}_{3}$ in severe disease such as COVID-19 may be probably due to the impaired biosynthesis of the hormonally active form of vitamin $\mathrm{D}$ and not a predisposing factor for the inflammatory reactions [31, 32].

In this study, decreased calcium (total, ionized, and corrected) and serum albumin in COVID-19 patients was observed when comparing with healthy individuals. Several studies have shown that the SARS-CoV-2 E gene encodes a few trans-membrane

Ta b l e. Comparison between COVID-19 patients and healthy individuals for all study parameters, $(n=90)$

\begin{tabular}{l|c|c|c}
\hline \multicolumn{1}{c|}{ Tests } & $\begin{array}{c}\text { COVID-19 } \\
\text { patients, } n=60\end{array}$ & $\begin{array}{c}\text { Healthy individuals, } \\
n=30\end{array}$ & $P$ value \\
\hline Mean age, year & $38.7 \pm 5.2$ & $35.2 \pm 4.8$ & $P=0.0027$ \\
$\alpha-\mathrm{MSH}, \mathrm{pg} / \mathrm{ml}$ & $386.57 \pm 132.86$ & $330.27 \pm 56.40$ & $P=0.029$ \\
1,25(OH) ${ }_{2} \mathrm{D}_{3}, \mathrm{ng} / \mathrm{ml}$ & $14.73 \pm 4.16$ & $22.8 \pm 4.6$ & $P<0.0001$ \\
Calcium, mg/dl & $8.28 \pm 0.60$ & $9.40 \pm 0.65$ & $P<0.0001$ \\
Ionized calcium, mg/dl & $4.24 \pm 0.45$ & $4.55 \pm 0.43$ & $P=0.0024$ \\
Corrected calcium, mg/dl & $8.44 \pm 0.80$ & $9.02 \pm 0.88$ & $P=0.0023$ \\
Albumin, g/dl & $3.78 \pm 0.74$ & $4.20 \pm 0.54$ & $P=0.007$ \\
Phosphorus, mg/dl & $3.94 \pm 0.40$ & $4.02 \pm 0.46$ & $P=0.397$ \\
Magnesium, mg/dl & $1.78 \pm 0.11$ & $1.92 \pm 0.20$ & $P<0.0001$ \\
\hline
\end{tabular}


proteins with ion channel activities that are highly expressed through infection. The ion channels are absorbent of calcium, and the impairments in calcium homeostasis can lead to the stimulation of inflammatory processes, producing edema and leading to damage of lung cells [33].

In hospitalized patients with COVID-19, hypocalcemia commonly occurs and leads to an unfavorable prognosis. The etiology of hypocalcemia in patients with COVID-19 is still cloudy but is likely multifactorial. Further research is urgently needed to know the causes of hypocalcemia in hospitalized COVID-19 patients. Calculation of the ionized calcium should be done because it is more accurate than corrected form of calcium in critically ill patients. However, calcium is mainly bind with plasma albumin, and reduction of albumin in serum may be one of the causes of low calcium. Also, hypoxia in lung tissue results in calcium influx and cell membrane damage. In COVID-19 patients, the pro-inflammatory cytokines cause the imbalance of calcium because of inhibition of the secretion of parathyroid hormone (PTH) and it is an impaired response [19,22,34].

In this study, phosphorus and magnesium levels in COVID-19 patients were decreased when compared with healthy individuals. Hypophosphatemia can be caused by one of three mechanisms: decrease phosphate intestinal absorption, phosphate transfer from the extracellular to the intracellular compartment (trans-cellular shift), increased phosphate renal excretion, or any variation of these mechanisms. The mechanisms that lead to hypophosphatemia in extreme COVID-19 patients remain cloudy. According to preview, the immunological activity of elderly patients with hypophosphatemia or severe pneumonia is lower than that in younger, and patients with hypophosphatemia are usually immunocompromised. [35-37].

Magnesium deficiency may reduce the resistance against infection with SARS-CoV-2 and, most notably, may enhance the severity of COVID-19. This condition leads to diabetes, cardiovascular diseases and chronic respiratory disorders in older age patients. When taking vitamin D supplements, magnesium supplementation is advised. Because it helps in the stimulation of vitamin $\mathrm{D}$ action that aids to regulate phosphate and calcium homeostasis, then eventually affects bone growth. All vitamin D metabolizing enzymes require magnesium for their activity, which works as a for enzymatic reactions in the liver and kidneys [38].
The major limitation during this study was the sample collection from patients in the isolated hospital during the COVID-19 pandemic that required special permission from the health ministry and it was a slow bureaucratic process.

In general, the results of this article focused on the serum level changes of alpha-MSH, vitamin D, calcium, phosphorus, and magnesium in COVID-19 patients. Therefore, these findings may be taken into consideration in the next updating protocols of the COVID-19 management and contribute to the cutting-edge field of molecular mechanisms of SARSCoV-2 influence on the overall state of patients.

Conclusions. In the current study, the COVID-19 patients revealed low serum levels of vitamin $\mathrm{D}$, calcium, and magnesium that may recommend them as supplements for those patients to increase the innate immune response against this virus. On the contrary, the $\alpha$-MSH level was high among COVID-19 patients.

Conflict of interest. Authors have completed the Unified Conflicts of Interest form at http://ukrbiochemjournal.org/wp-content/uploads/2018/12/ coi_disclosure.pdf and declare no conflict of interest.

Funding. The authors declare this study was carried out under the supervision of the Ministry of Higher Education and Scientific Research and has not been supported by any Grant.

\section{РІВЕНЬ АЛЬФА- МЕЛАНОЦИТСТИМУЛЮВАЛЬНОГО ГОРМОНУ, ВІТАМІНУ D, КАЛЬЦІЮ, ФОСФОРУ ТА МАГНІЮ У СИРОВАТЦІ КРОВІ ПАЦІЕНТІВ ІЗ COVID-19}

\author{
S. Z. Hussein ${ }^{1}$, M. A. Abdalla ${ }^{2 \bowtie}$ \\ ${ }^{1}$ Clinical Biochemistry Unit, Salah Aldeen \\ Health Directorate, Tikrit, Iraq; \\ ${ }^{2}$ Department of Human Anatomy, Tikrit \\ University College of Medicine, Tikrit, Iraq; \\ 凶e-mail: dr.mohammad68@tu.edu.iq
}

Пандемія COVID-19 виникла i швидко поширилася світом. 3 метою покращення стану пацієнтів із COVID-19 важливо визначити можливі клінічні диференціальнодіагностичні маркери та їх кореляцію 3 тяжкістю інфекції SARS-CoV-2. У цьому дослідженні було проаналізовано рівень $\alpha$-меланоцитстимулювального гормону 
$(\alpha-\mathrm{MC})$, вітаміну $\mathrm{D}$, кальцію, фосфору та магнію у сироватці крові пацієнтів із COVID-19. Зразки крові було взято у 60 пацієнтів, які відвідували ізольовану лікарню в місті Тікріт/ Ірак 3 вересня по грудень 2020 року і були діагностовані за допомогою ПЛР тесту як позитивні на COVID-19, а також у 30 здорових людей. У пацієнтів із COVID-19 виявлено високі рівні $\alpha$-МСГ у сироватці крові у порівнянні зі здоровими людьми, але низькі рівні вітаміну $\mathrm{D}$, кальцію та магнію, які можуть бути рекомендовані як добавки для підвищення імунної відповіді цих пацієнтів.

К л юч ов і слов а: COVID-19, альфаМСГ, кальцій, магній, вітамін D.

\section{References}

1. Lu H, Stratton CW, Tang YW. Outbreak of pneumonia of unknown etiology in Wuhan, China: The mystery and the miracle. $J$ Med Virol. 2020; 92(4): 401-402.

2. Moscowitz AE, Asif $\mathrm{H}$, Lindenmaier LB, Calzadilla A, Zhang C, Mirsaeidi M. The Importance of Melanocortin Receptors and Their Agonists in Pulmonary Disease. Front Med (Lausanne). 2019; 6: 145.

3. Wang W, Guo DY, Lin YJ, Tao YX. Melanocortin Regulation of Inflammation. Front Endocrinol (Lausanne). 2019; 10: 683.

4. Gatti S, Lonati C, Sordi A, Catania A. Protective effects of melanocortins in systemic host reactions. Adv Exp Med Biol. 2010;681:117-125.

5. Nayaf MS, Ahmed AA, Abdalla MA. Alopecia areata and serum vitamin D in Iraqi patients: A Case-Control Study. Prensa Med Argent. 2020; 106(3): 287.

6. Abdalla MA, Nayaf MS. Evaluation of serum $\alpha$-MSH level in melasma. WJPMR. 2018; 4(5): 29-32.

7. Rija FF, Almahdawi ZM, Hussein SZ. Evaluation of bone metabolism biomarkers in hemodialysis chronic kidney disease. Indian J Public Health. 2019; 10(4): 1660-1665.

8. Hussein SZ, Ali SJ. Serum thyroid hormones and cortisol in patients with chronic renal failure. Med J Tikrit Univ. 2019; 25(1): 1-6.

9. Rija FF, Almahdawi ZMM, Hussein SZ. Correlation between calcium sensing receptor with other calcium regulators in osteoporosis and osteomalacia patients. Plant Archives. 2019; 19(1): 1199-1207.
10. Li D, Taylor AW. Diminishment of alpha-MSH anti-inflammatory activity in MClr siRNAtransfected RAW264.7 macrophages. J Leukoc Biol. 2008; 84(1): 191-198.

11. Rija FF, Hussein SZ, Abdalla MA. Physiological and immunological disturbance in rheumatoid arthritis patients. Baghdad Sci J. 2021; 18(2): 247-252.

12. Getting SJ, Perretti M. MC3-R as a novel target for antiinflammatory therapy. Drug News Perspect. 2000; 13(1): 19-27.

13. Lee DJ, Taylor AW. Following EAU recovery there is an associated MC5r-dependent APC induction of regulatory immunity in the spleen. Invest Ophthalmol Vis Sci. 2011; 52(12): 88628867.

14. Clemson CM, Yost J, Taylor AW. The role of alphaMSH as a modulator of ocular immunobiology exemplifies mechanistic differences between melanocortins and steroids. Ocul Immunol Inflamm. 2017; 25(2): 179-189.

15. Harris E, Tiganescu A, Tubeuf S, Mackie SL. The prediction and monitoring of toxicity associated with long-term systemic glucocorticoid therapy. Curr Rheumatol Rep. 2015; 17(6): 513.

16. Abdalla MA, Nayaf MS, Hussein SZ. Evaluation of vitamin D in melasma patients. Rev Romana Med Lab. 2019; 27(2): 219-221.

17. Aranow C. Vitamin D and the immune system. $J$ Investig Med. 2011; 59(6): 881-886.

18. Grant WB, Lahore H, McDonnell SL, Baggerly CA, French CB , Aliano JL, Bhattoa HP. Evidence that Vitamin D Supplementation Could Reduce Risk of Influenza and COVID-19 Infections and Deaths. Nutrients. 2020; 12(4): 988.

19. Bazydlo LAL, Needham M, Harris NS. Calcium, magnesium, and phosphate: a review article. Lab Med. 2014; 45(1): e44-e50.

20. Nieto-Torres JL, Verdiá-Báguena C, JimenezGuardeño JM, Regla-Nava JA, CastañoRodriguez C, Fernandez-Delgado R, Torres J, Aguilella VM, Enjuanes L. Severe acute respiratory syndrome coronavirus $\mathrm{E}$ protein transports calcium ions and activates the NLRP3 inflammasome. Virology. 2015; 485: 330-339.

21. Zhao Y, Li Z, Shi Y, Cao G, Meng F, Zhu W, Yang GE. Effect of hypophosphatemia on the withdrawal of mechanical ventilation in patients with acute exacerbations of chronic obstructive pulmonary disease. Biomed Rep. 2016; 4(4): 413416. 
22. Zhou Y, Frey TK, Yang JJ. Viral calciomics: interplays between $\mathrm{Ca}^{2+}$ and virus. Cell Calcium. 2009; 46(1): 1-17.

23. De Baaij JHF, Hoenderop JGJ, Bindels RJM. Magnesium in man: implications for health and disease. Physiol Rev. 2015; 95(1): 1-46.

24. Catania A, Gatti S, Colombo G, Lipton JM. Targeting melanocortin receptors as a novel strategy to control inflammation. Pharmacol Rev. 2004; 56(1): 1-29.

25. Sunlong Biotech CO. Human Elisa kit. Available from: https://www.sunlongbiotech.com/gory. php?id=66. [Accessed 2 December 2020]

26. Lasaga M, Debeljuk L, Durand D, Scimonelli TN, Caruso C. Role of alpha-melanocyte stimulating hormone and melanocortin 4 receptor in brain inflammation. Peptides. 2008; 29(10): 18251835.

27. Abdalla MA, Nayaf MS, Hussein SZ. Correlation between serum $\alpha$-MSH and vitamin D levels in vitiligo patients. Iran J Dermatology. 2020; 23(4): 163-167.

28. Huang C, Wang Y, Li X, Ren L, Zhao J, Hu Y, Zhang L, Fan G, Xu J, Gu X, Cheng Z,Yu T, Xia J, Wei Y, Wu W, Xie X, Yin W, Li H, Liu M, Xiao Y, Gao H, Guo L, Xie J, Wang G, Jiang R, Gao Z, Jin Q, Wang J, Cao B. Clinical features of patients infected with 2019 novel coronavirus in Wuhan, China. Lancet. 2020; 395(10223): 497-506.

29. Gombart AF, Pierre A, Maggini S. A Review of Micronutrients and the Immune SystemWorking in Harmony to Reduce the Risk of Infection. Nutrients. 2020; 12(1): 236.

30. Daneshkhah A, Agrawal V, Eshein A, Subramanian H, Roy HK, Backman V. Evidence for possible association of vitamin D status with cytokine storm and unregulated inflammation in COVID-19 patients. Aging Clin Exp Res. 2020; 32(10): 2141-2158.

31. Mitchell F. Vitamin-D and COVID-19: do deficient risk a poorer outcome? Lancet Diabetes Endocrinol. 2020; 8(7): 570.

32. Nieto-Torres JL, DeDiego ML, VerdiáBáguena C, Jimenez-Guardeño JM, ReglaNava JA, Fernandez-Delgado R, CastañoRodriguez C, Alcaraz A, Torres J, Aguilella VM, Enjuanes L. Severe acute respiratory syndrome coronavirus envelope protein ion channel activity promotes virus fitness and pathogenesis. PLoS Pathog. 2014; 10(5): e1004077.

33. Hu ZD, Huang YL, Wang MY, Hu GJL, Han YQ. Predictive accuracy of serum total calcium for both critically high and critically low ionized calcium in critical illness. J Clin Lab Anal. 2018; 32(9): e22589.

34. Fong J, Khan A. Hypocalcemia: updates in diagnosis and management for primary care. Can Fam Physician. 2012; 58(2): 158-162.

35. Leung J, Crook M. Disorders of phosphate metabolism. J Clin Pathol. 2019; 72(11): 741-747.

36. Koumakis E, Cormier C, Roux C, Briot K. The Causes of Hypo- and Hyperphosphatemia in Humans. Calcif Tissue Int. 2021; 108(1): 41-73.

37. Rija FF, Hussein SZ, Abdalla MA. Osteoprotegerin, sclerostin, and osteocalcin serum levels in thyroid disorder patients. Ukr Biochem J. 2021; 93(5): 117-121.

38. Uwitonze AM, Razzaque MS. Role of Magnesium in Vitamin D Activation and Function. $J$ Am Osteopath Assoc. 2018; 118(3): 181-189. 